\title{
TOUGH CHOICES FOR AN AGILE OPEN SOURCE INTERNATIONAL DEVELOPMENT PROJECT: THE LIBRE LAS CASE
}

\author{
Andrew McDowell \\ Victoria University of Wellington, Wellington, New Zealand \\ mcdoweandr@myvuw.ac.nz
}

Andreas Drechsler (corresponding author)

23 Lambton Quay, Pipitea Campus

PO Box 600, Wellington 6140, New Zealand

Victoria University of Wellington, Wellington, New Zealand

Phone: +64 4 463-5265

andreas.drechsler@vuw.ac.nz

Running Head: Tough Choices for an Open Source Project 


\title{
TOUGH CHOICES FOR AN AGILE OPEN SOURCE INTERNATIONAL DEVELOPMENT PROJECT: THE LIBRE LAS CASE
}

\author{
Teaching Case (29 pages)
}

\begin{abstract}
$\underline{\text { ABSTRACT }}$
In June 2010, the Food and Agriculture Organization (FAO) of the United Nations (UN) started a three year, trust fund project to develop and pilot open source cadastre and registration software. This project was called Libre Land Administration System (Libre LAS) and its aim was to make computerized cadastre and registration systems more affordable and more sustainable in developing countries. The first stage of the Libre LAS project was undertaken at FAO headquarters (HQ) in Rome. Generic cadastre and registration processes were defined and software requirements and software architecture documents prepared. Development of the Libre LAS software began in early 2011. An international team of software developers assembled at FAO HQ and proceeded to create the generic software platform using an Agile Scrum methodology. By early 2012, the first release of Libre LAS was ready and pilot implementations began in Ghana, Nepal, and Samoa to validate and prove the Libre LAS concept. This case study tracks the initial development and implementation of Libre LAS in the pilot countries from 2011 to late 2012. It is presented from the standpoint of Brett, the Libre LAS Project Coordinator, and discusses organisational, cultural, stakeholder, and financial issues that conspired to derail the project. Ultimately, Brett is left to make some tough decisions around the pilot implementations to ensure the success of the overall project.
\end{abstract}


Keywords: open source software, agile development, project management, non-profit organization, international development, land administration software, teaching case This case is based on a real project; however, names, dates, details, and supporting artefacts have been altered to protect the privacy of individuals and to make the case situation more suitable for class discussion. Any views expressed do not necessarily reflect the views or policies of any organisation or individual represented by this case. This teaching case was developed as a basis for class discussion and is not designed to illustrate effective or ineffective handling of an administrative situation. 


\section{INTRODUCTION}

Brett was sitting in the Blue Bar on the $8^{\text {th }}$ floor of Food and Agriculture Organization (FAO) headquarters (HQ), sipping his morning caffé espresso. He had been at HQ for nearly 6 months and had become accustomed to the strong shot of coffee the Italians so enjoyed. As he sipped he looked out over the view in front of him. Directly across the road was the Circo Massimo, a chariot race track in Roman times capable of seating 250,000 people. To the north was an unobstructed view of the ancient Roman Forum with the Colosseum beside it. HQ had originally been commissioned by Mussolini in 1938 to house the Ministry of Italian Africa. Building work was delayed by the war and the missive eight story white marble edifice was not completed until 1952. The Italian State then assigned the right of extraterritoriality to it and leased it to the UN as the FAO HQ for the sum of one US dollar per year; the lease to be paid yearly in advance (Wikipedia, 2016).

To say the building did not blend in with its ancient surroundings was an understatement. Inside, it was a rabbit warren of mirrored corridors and small enclosed offices. It was not unheard for new FAO staff to get lost for hours trying to find a room or in many cases, the exit. In some ways, the building was an apt reflection of the FAO, a highly bureaucratic and compartmentalized organisation that held strong to its roots from previous decades. FAO had long been criticised for its inability to deliver on its core goals to eradicate hunger, eliminate poverty, and achieve sustainable management of natural resources (BBC, 2002; Campesina, 2006; Hancock, 1992; Pilon, 1988). Lofty goals undoubtedly, but a poor track record over nearly 40 years and a reputation for talking rather than doing had slowly eroded FAO's goodwill with many of the countries and non-government organisations (NGOs) it worked with (Fresco, 2006). To try and address these concerns, FAO had triggered a comprehensive programme of organisational reform and culture change to create a flatter, more responsive 
structure (FAO, 2013a). That programme had begun in 2009. It was now early 2011 and the programme was ongoing; there was still much to be done to pull FAO into the modern era.

Regardless of the organisational challenges, FAO was the correct vehicle to drive the Libre Land Administration System (Libre LAS) project, and it was the reason Brett had accepted the contract position of Libre LAS Project Coordinator. FAO had the reach, contacts and clout to coordinate the project over multiple regions as well as secure funding; a three-year trust fund totalling US $\$ 3$ million, funded by the Ministry of Foreign Affairs of Finland. The project was in-line with the FAO's five strategic objectives (FAO, 2013b), namely:

1. Help eliminate hunger, food insecurity and malnutrition

2. Make agriculture, forestry and fisheries more productive and sustainable

3. Reduce rural poverty

4. Enable inclusive and efficient agricultural and food systems

5. Increase the resilience of livelihoods to threats and crises

The project also fitted perfectly with FAO's broader initiative to develop the Voluntary Guidelines on Responsible Governance of Tenure for Land, Fisheries and Forests (VGGT) (FAO, 2012). The guidelines promoted transparency, equality and security in all governance aspects related to tenure and one of the best ways to achieve this was through automation of land administration. Many developing countries had tried to establish Land Administration Systems (LAS) with varying degrees of success. Cost, flexibility, and sustainability often meant the systems were ineffective or poorly utilized. Open-source software specifically designed to meet the needs of the cadastre and land registration systems was recognised as a key part of the solution that would make land administration automation available to all countries. This is where the Libre LAS project fitted in. 
The aim of Libre LAS was to 'make computerized cadastre and registration systems more affordable and more sustainable in developing countries'. The generic software would encompass best practices in land administration and service delivery, provide robust data management, and be capable of supporting enterprise wide deployments. Most importantly the software would be open source and freely available. As the laws and practices governing land administration are often unique to a country, the software would be designed to support customization. This activity would be undertaken by local developer resources trained in the Libre LAS development environment to ensure the ongoing sustainability of the software.

The Libre LAS three-year project plan allowed for six months of requirements analysis and technical architecture design, one year for the development of the generic software followed by one year for three pilot implementations in Ghana, Nepal, and Samoa. The pilots would be undertaken in parallel with mentoring and support from the FAO development team. The last six months of the project would provide early life software support to the pilots.

Brett had been working on the requirements analysis since his arrival in July and had also sought assistance for the architecture from an Australian IT consulting company. Both deliverables were now largely completed. Today was the day the rest of the Libre LAS team would arrive in Rome to start development of the generic software. Brett was hoping they did not get lost on their first day. At least he had managed to secure one of the larger offices in the building with room for eight people. He was hoping that would allow the team to form a cohesive working relationship.

\section{FEBRUARY 2011: PROJECT KICKOFF MEETING}

Brett Welcome everyone, I trust you got through security and found the office OK. It can be a little hard to find your bearings in here. I thought we would get started with a round of introductions. Nigel, would you like to start? 
Nigel Hi, I am Nigel and I am from Sydney, Australia. I have worked as an IT consultant for around 10 years building custom enterprise systems for both governments and commercial clients. My main area of interest is solutions architecture. I worked on the New South Wales land administration system for around four years and I have also been working with Brett remotely over the last four months to prepare the solution architecture document for Libre LAS.

Pjeter Përshëndetje, my name is Pjeter. I am Albanian, but now live in the Netherlands. I have also worked as a software developer for 10 years with the last 6 years focused in Geographic Information Systems (GIS).

Anatoly Hello, I am Anatoly and I come from Bishkek in Kyrgyzstan. I have been software developer since 1999 and worked on national and international projects. I worked on development of automated land registration system with cadastre module in Kyrgyzstan and on pilot implementation of land registration system in Tajikistan.

Rosa Ciao, I am Rosa. I live in Roma. I trained in ancient roman law and was a lawyer for several years. For the last 11 years, I have worked with an Italian software development company as a programmer and usability specialist.

Sabir Hello, I am Sabir. I work for the Lands Commission in Accra, Ghana. I haven’t done software development before but I am looking forward to being part of the team and learning some new skills ready for the Ghana pilot. 
James I am James. I am also from the Lands Commission in Ghana and I work with Sabir. I am also looking forward to being part of the team.

Brett Thanks everyone. Right, I am Brett, but you know that already. Like Nigel, I am from Sydney, Australia. I am a qualified surveyor and I worked with the New South Wales Survey Board for nearly 25 years. I joined FAO about 6 months ago as the coordinator for this project, but prior to that I was a freelance consultant working on various international land administration projects, most of which involved computerization.

OK, to get underway I thought Nigel could introduce the Libre LAS architecture for the generic software and from there we can try planning our first sprint.

Nigel You can see the three-tier, web services based architecture of the Libre LAS software in Figure 1. A two-dimensional layering approach was used to structure the software firstly by responsibility and secondly for reuse. The three structural responsibilities are Presentation (Desktop), Business Logic (Services) and Data. The Business Logic and Data layers were further partitioned into business concepts using web services and Enterprise Java Beans (EJBs) to promote component reuse. Security of tenure data was a primary consideration and industry standard approaches were used for all security aspects. External systems such as Map Servers were also integrated to provide raster map imagery and enhance map navigation... 
After months of planning, Brett almost felt relief at finally getting the development underway. He was really looking forward to using Scrum for the development. He had not used it before, but Nigel had used it several times and had recommended it for the development of the generic software. It sounded like a fresh and exciting approach, however one sneaking concern that Brett had was that none of the other team members had used it before. To mitigate the risk, Nigel would mentor the team members by acting as the Scrum Master. Brett had previously worked with Nigel, Pjeter and Anatoly, so he knew they were all strong software developers experienced in building land administration systems. He figured that any initial delays caused by the adoption of the new approach would smooth out as the team started producing code.

One of the advantages of Scrum is that greatly simplified the project roles. Brett would be the Product Owner and act as the primary interface with FAO, Nigel would hold a dual role as Scrum Master while also being part of the team working alongside Anatoly, Pjeter, Rosa, James and Sabir. Recognising that some of the members had specialist skills, it was decided to appoint development leads to make the best use of those skills. Nigel was assigned as lead for the overall architecture and business logic components, Pjeter as the lead for database development and GIS components, Anatoly as the lead for the desktop application and web services with Rosa as the lead for usability and software quality and testing.

James and Sabir had limited software development experience, so it was agreed they would work closely with the more experienced members of the team to help guide them through their development tasks. Brett had not initially planned for the Ghanaians to join the development in Rome, but the opportunity to bring them on board and train them up as ongoing support for the Ghana pilot had been too good to turn down. It had been the CEO of the Lands Commission in Ghana that had raised the idea. He was a strong supporter of Libre LAS concept, and he had specifically requested the inclusion of the Ghana pilot at one of the 
FAO conferences. He also requested that two of his people join the initial development effort so they could ensure that any Ghanaian requirements would be considered. Brett realized that making James and Sabir part of the development team would greatly increase the chances of success for the Ghana pilot, so he readily agreed to the request.

\section{JUNE 2011: THE GHANAIAN EXPERIMENT}

Brett reflected over the last six sprints. The development was a little behind where he wanted it to be, but it was progressing. What was clear was the plan to bring the Ghanaian's on board so they could be part of the development team was not working out. Neither Sabir nor James had really contributed much. James had quickly given up on his development tasks and spent most of his time researching various topics of interest on the internet. Sabir was a different story, he had initially engaged and tried to convince Nigel that part of the architecture should be changed based on his research of various development websites. Nigel pointed out that the change would directly impact the scalability of the software and would add complexity. Sabir did not seem overly convinced, but he accepted Nigel's comments and development continued. After that, Sabir seemed content to bide his time, focusing on his Italian lessons, without making a great deal of progress on his development tasks.

Brett was not overly concerned about the failed experiment to create software developers from the Ghanaians. During his trip to Ghana at the end of 2010, Brett had talked to a few contract software developers in Accra, so he was confident he could source suitable local developer resources for the customisation effort. If nothing else the Ghanaians were being exposed to the Scrum development methodology, so they could at least champion the approach when they returned home. The original plan had been to keep the Ghanaians in Rome for the full year, but Brett now realized it would be more beneficial to send them back home a few months early. That way they could start preparing the customisation requirements 
and lay the ground work for the pilot. That should give the Ghana pilot a head start and help to mitigate some of the pilot risks.

The Ghana pilot team was also starting to take shape. Sabir had already agreed to take on the role of Product Owner, which Brett felt would smooth the way for Libre LAS to be adopted by the Lands Commission. Sabir was well respected within the commission and he had the ear of the CEO. Pjeter had also agreed to work on the Ghana pilot and provide technical support and mentoring. He was a capable software developer and both he and Sabir seemed to get on well. They were both Muslim and often attended prayer service together. Brett hoped their shared beliefs would help to stabilise and direct the customisation efforts in Ghana.

For the other pilots, Nigel had agreed to assist Samoa, and Anatoly had agreed to assist Nepal, while Rosa would stay in Rome to support the generic software. Brett was a little unsure how effectively Nigel, Anatoly and Pjeter would fill their mentor roles. All three were capable software developers / architects, but the skills required for software development were not the same as the soft skills that would be required to deliver the pilot projects. When FAO prepared the original project budget, they had decided a specialist project manager for each pilot was not justified. It was one of the reasons Brett had agreed on using Scrum. With Scrum, the responsibility for delivering the project is shared by the team rather than relying on a project manager for direct governance and control. As contingency, Brett had increased the travel budget so that he could visit the pilots frequently. That way he could be on the ground to smooth over any issues or concerns that might arise.

\section{MARCH 2012: FUNDING TROUBLE}

Brett hung up the phone. The call was from reception; the Finns were on their way up. He checked his presentation for the last time, everything looked in order. The project status page 
had a few talking points to get things underway. He would follow that up with a live demonstration of the generic Libre LAS software before segueing into a couple of the lessons learned from the retrospective the team had completed back in December. There was a slide with progress on the pilots, although it was still early days so apart from Ghana, there was not a lot to report. Most importantly, he had the summary expenditure sheet at the end to cover off the project finances. They were still looking healthy. There had been some savings when the Ghanaians returned home a few months early and the open source tools the team used meant he had not needed to use any of the software license budget. The strong financial position should be enough to convince the Finns to release the last US $\$ 600,000$ to the project.

The meeting started well. Brett stepped through the talking points and ran through the live demonstration without a hitch. The two Finns in attendance had several questions about the software which Brett either answered and/or demonstrated to their satisfaction before discussing the lessons learned by the team. Next was the discussion on the pilots. It was early days, but both Samoa and Nepal had got underway the month before and they were making good progress preparing their Customisation Strategies. The Samoa strategy was due for signoff in the following week and development would begin shortly after that. Nepal still had a few weeks work before it was ready to start. An unexpected delay occurred because the Lands Ministry in Nepal did not have any suitable office space available to accommodate the pilot team, so it had been necessary to hire an office close by. It was currently being fitted out with desks, network connections and computers.

Ghana was somewhat more complex and there had been a few issues. The initial scope for the Ghana pilot focused on the greater Accra region, but The World Bank (WB) was in the process of launching a major lands project covering all of Ghana, which they were targeting for later in the year. Brett had spoken with the WB Team Lead and they were very interested 
in expanding the Libre LAS pilot across the country. That had forced the pilot team to consider the broader requirements that might be in play. The WB were also concerned by some of the business practices in the Lands Commission and so they were pushing for reengineering of the workflow processes. Sabir and James were working through that to see what they could accommodate in the pilot. Another issue for the Ghana pilot was that the Lands Commission CEO had been suspended from duty because of procurement irregularities. Brett did not have a lot of details, but the issue sounded serious. The replacement CEO was unlikely to share the same level of enthusiasm for the Ghana pilot as the previous CEO, which might have downstream impacts for the pilot.

Brett continued by outlining the arrangements for the pilot developers. For Samoa, the project had partnered with a software development firm (ABC Soft) to secure two local software developers (Chris and Manu). A similar arrangement had been made in Nepal where three local software developers were assigned (Paras, Dipendra and Naresh). Developers for Ghana had not yet been confirmed, but Brett explained that he had recently completed interviews with some independent contract software developers, two of which looked suitable (Isaac and Kwadwo). Brett was planning to finalise contracts with them during his visit to Accra the following week.

Finally, it was time talk through the project finances (Figure 2). In short, the project was in a good position, tracking US \$140,000 under budget with current expenditure of US \$1.27 million compared to the budget of US $\$ 1.32$ million. There was plenty of headroom to make it through to September when the final tranche of US $\$ 600,000$ would be made available, which Brett had already earmarked to fund the completion of the pilots and to provide support for all three pilots over the first six to nine months of operation. The Finns were shaking their heads in agreement, they seemed suitably impressed, which is why Brett was 
floored by their next question: "In your opinion, how would the project fare without the remaining funds?"

Alarm bells were ringing in Brett's head. He had been careful to keep close tabs on the project budget so that the project would be in the best position to deliver the pilots, but the last thing he needed was to lose $20 \%$ of the funding. He asked the Finns to clarify; they were reviewing their commitments to FAO, as they currently supported three projects and the newly elected Finnish government had issued a directive to reduce donor funding over the coming year. Brett had to think quickly; the main risk from reduced funding was the sustainability of the pilots. It would be difficult to get all three pilots over the line and it would be a real struggle to provide early life support as the final tranche was intended to cover costs to run the FAO team through to mid-2013. With that, the meeting was over. The Finns advised they would report back to their ministry and advise Brett by mid-June of any decision.

Later that day, Brett meet with Richard the Director for the Land Tenure team at FAO to discuss the outcome of the meeting with the Finns.

Richard Yes, I heard the Finns were looking to cut one or two of their projects loose. I think the other two projects are not as well positioned as Libre LAS. The risk is the Finns have never really been interested in Land projects. Ronald used some of his contacts to line up the funding before he went to the WB. You might want to move forward with the assumption no more funds are coming from the Finns.

Brett That is the feeling I got as well. Are there any other funding options available? 
Richard There might be. The Department of International Development (UK DFID) has a project coming up in Nigeria looking at systematic registration of lands. There could be an opportunity for Libre LAS but initial discussions on that project will not happen until August.

I also heard through the grapevine that the Lands Automation Project in Lesotho has hit a few problems. The current vendor is looking to pull out. That project is funded as part of the Lesotho Compact with the Millennium Challenge Corporation (MCC). I have a contact at the MCC so I can see if I can arrange a meeting for you.

Brett Thanks Richard. What about FAO project funds?

Richard There is not a lot available. You might get lucky with a Technical Cooperation Programme (TCP) facility for Nepal. All the other project funds are allocated and with the restructure that is going on, I expect those funds to be cut further in the next financial year. I have been constantly called into meetings over the last few months to see where we can make more efficient use of our existing funds, so until the restructure is bedded in, introducing new project costs is out of the question.

\section{DECEMBER 2012: DECISION TIME}

It was a cold mid-December night in Rome when Brett ended the Skype call with Nigel. Nigel had just returned to Australia and had called with an update on Samoa (Figure 5). It was not the news Brett wanted to hear, especially after having reviewed the most recent 
progress reports on Ghana (Figure 3) and Nepal (Figure 4). Samoa was only partially operational; the Survey section was up and running, capturing surveys into Libre LAS, but the Land Registration section had decided to stick with the old system because they were not confident using the new software. One of the staff from the Land Registration section had worked hard to come up to speed with the system, but it had been difficult to motivate the other four staff, particularly the section leader, who had not attended any of the software training sessions. Nigel had tried some one on one training, but the section was extremely busy in the lead up to Christmas and he had only managed to spend a couple of hours with them. The Ministry would be on a two-week break over Christmas and New Year and Nigel was on holiday until January $20^{\text {th }}$, so the earliest he could return to Samoa for follow up training was late January or early February.

Brett was already part way through preparing the Terminal Report which FAO and the project partners would use to judge the overall success of the Libre LAS programme. Failing to implement at least one of the three pilots would not look good and it would make the task of sourcing new funding for the continued development of software extremely difficult. For the last six months Brett had focused on trying to find a new source of funding for the project, but he had not been successful. The initiatives in Nigeria and Lesotho - as suggested by Richard - looked hopeful, but it was still some months off before they could be confirmed. The search for funds had distracted him from supporting the pilots as much as he had planned and he could see from the status reports his absence had impacted both Ghana and Nepal more than he had anticipated.

Brett realised that he needed to make some tough decisions. He still had US $\$ 96,000$ funds he had managed to put aside to cover the initial support period for the pilot implementations. The question was, how should he spend the money? Should he persist trying to win new funding, or should he focus on trying to get as many pilots over the line as possible? There 
was also one other hard constraint he had to juggle. The deadline for the final Terminal Report was February $20^{\text {th }} 2013$.

\section{CASE QUESTIONS AND ASSUMPTIONS}

Take Brett's perspective as FAO contractor and Libre LAS Project Coordinator and recommend a future course of action for him. To guide the development of your recommendation, consider answering the following questions:

1. Identify key aspects of the Libre LAS project environment, the project stakeholders and the project situation that are relevant for Brett's decision-making

2. Conduct a thorough analysis of these factors and support your analysis drawing on project management literature, for instance regarding

a. typical project management mistakes (Nelson, 2007)

b. the project's alignment (Alsudiri et al., 2013) to the FAO's vision and strategy

c. project portfolio management approaches (Jeffery and Leliveld, 2004)

d. project risk management practices (Zhang, 2011)

3. Identify clear action alternatives for Brett going forward and discuss pros and cons for each alternative

4. Give and justify a recommendation for Brett regarding the most promising option to pursue

5. Discuss your recommendation in-class and contrast it with others' recommendations. Can you achieve a consensus on how to proceed?

Base your considerations on the following assumptions:

1. All of team members are contractors. If the project is wound up, or put on hold for a short period, they may not be available again to support the project.

2. Brett has complete decision making authority in terms of how the project is 
managed. He may need to inform FAO of his decisions, but there is no evidence that he needs to consult closely with them or get their specific permission to choose a course of action.

3. Failure of all three pilots effectively represents failure of the overall project. This is likely to make it extremely difficult to secure additional funding for the generic project as potential sponsors would note the project was not successful in any of the three pilot countries.

As final exercise, consider and discuss what could Brett have done differently from the start of the project to prevent the unsatisfactory situation he is faced with at the end of the case? Use this opportunity to reflect on the implications of the FAO's nature as non-profit organisation and UN subsidy regarding the applicability of established (= business organization-focused) project management literature to FAO-sponsored projects such as Libre LAS.

\section{REFERENCES}

Alsudiri, T., Al-Karaghouli, W. and Eldabi, T. (2013). Alignment of large project management process to business strategy: A review and conceptual framework, Journal of Enterprise Information Management 26(5): 596-615.

BBC. (2002). BBC NEWS | In Depth | Food summit 'waste of time'. Retrieved July 17, 2017, from http://news.bbc.co.uk/2/hi/2042664.stm

Campesina. (2006). La Via Campesina : International Peasant Movement - World Food Summit: 10 years of empty promises. Time for food sovereignty! Retrieved July 17, 2017, from

https://web.archive.org/web/20090210055905/http://www.viacampesina.org/main_en/ index.php?option=com_content $\&$ task=view\&id=233\&Itemid=27

FAO. (2012). Voluntary Guidelines on the Responsible Governance of Tenure of Land, Fisheries and Forests in the Context of National Food Security. Retrieved from http://www.fao.org/docrep/016/i2801e/i2801e.pdf

FAO. (2013a). FAO Reform: Looking forward. Retrieved from http://www.fao.org/docrep/018/mg881e/mg881e.pdf

FAO. (2013b). The FAO Strategic Objectives. Retrieved from https://www.youtube.com/watch?v=-pFi23tFJ6s 
Fresco, L. (2006, May 14). Resignation letter of Louise Fresco, ADG, FAO, The Guardian. Retrieved from http://www.theguardian.com/world/2006/may/14/foodanddrink

Hancock, G. (1992). Lords of poverty: The power, prestige, and corruption of the international aid business, Atlantic Monthly Press.

Jeffery, M. and Leliveld, I. (2004). Best Practices in IT Portfolio Management, MIT Sloan Management Review 45(3): 41-49.

Nelson, R. R. (2007). IT Project Management: Infamous Failures, Classic Mistakes, and Best Practices, MIS Quarterly Executive 6(2): 67-78.

Pilon, J. G. (1988). The UN's Food and Agriculture Organization: Becoming Part of the Problem, Heritage Foundation.

Wikipedia. (2016, January 12). FAO Building, Rome, In Wikipedia. Retrieved from https://en.wikipedia.org/w/index.php?title=FAO_Building,_Rome\&oldid=699464958

Zhang, H. (2011). Two schools of risk analysis: A review of past research on project risk, Project Management Journal 42(4): 5-18. 


\section{FIGURES}

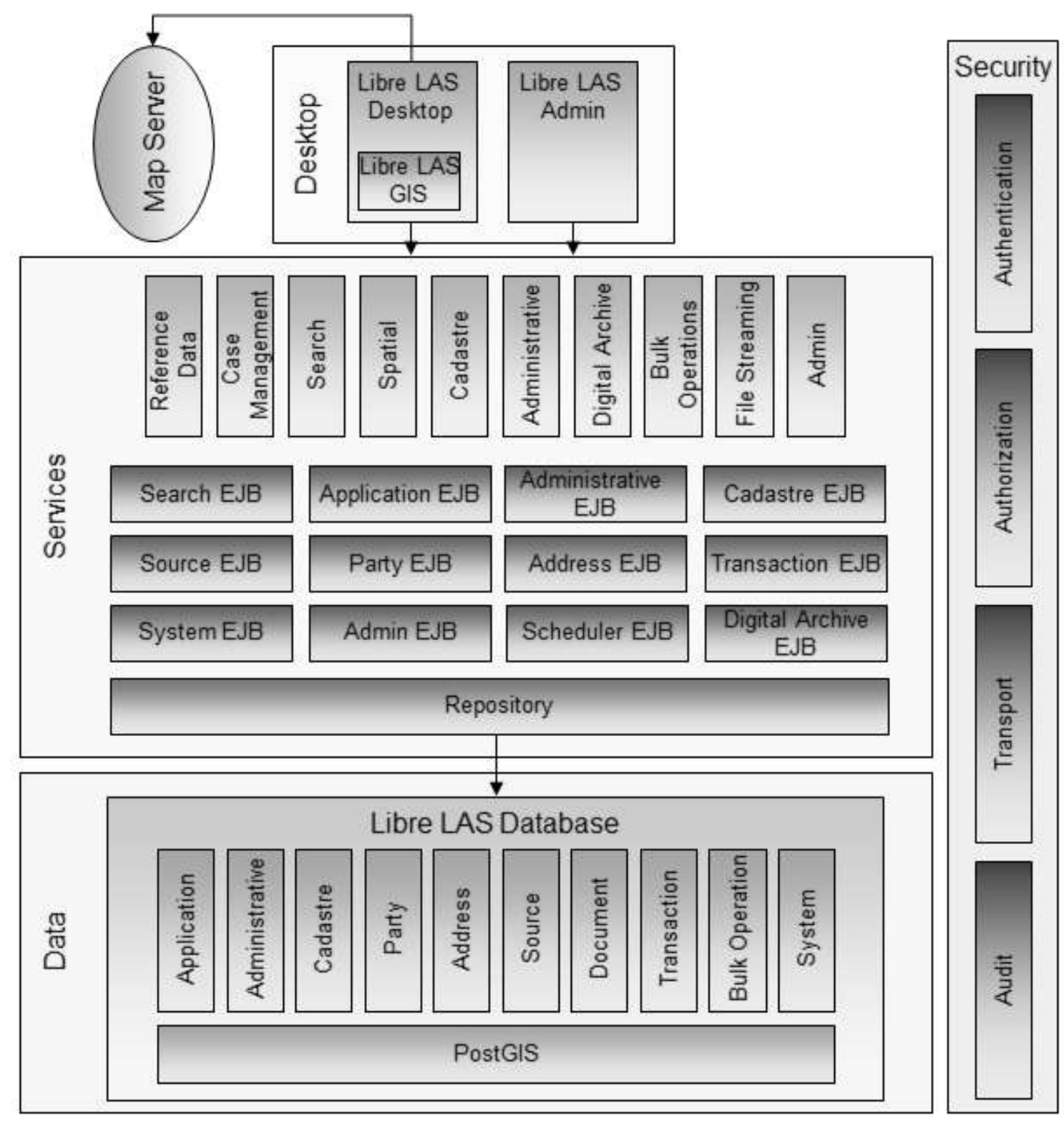

Figure 1 - The Libre LAS Software Architecture 


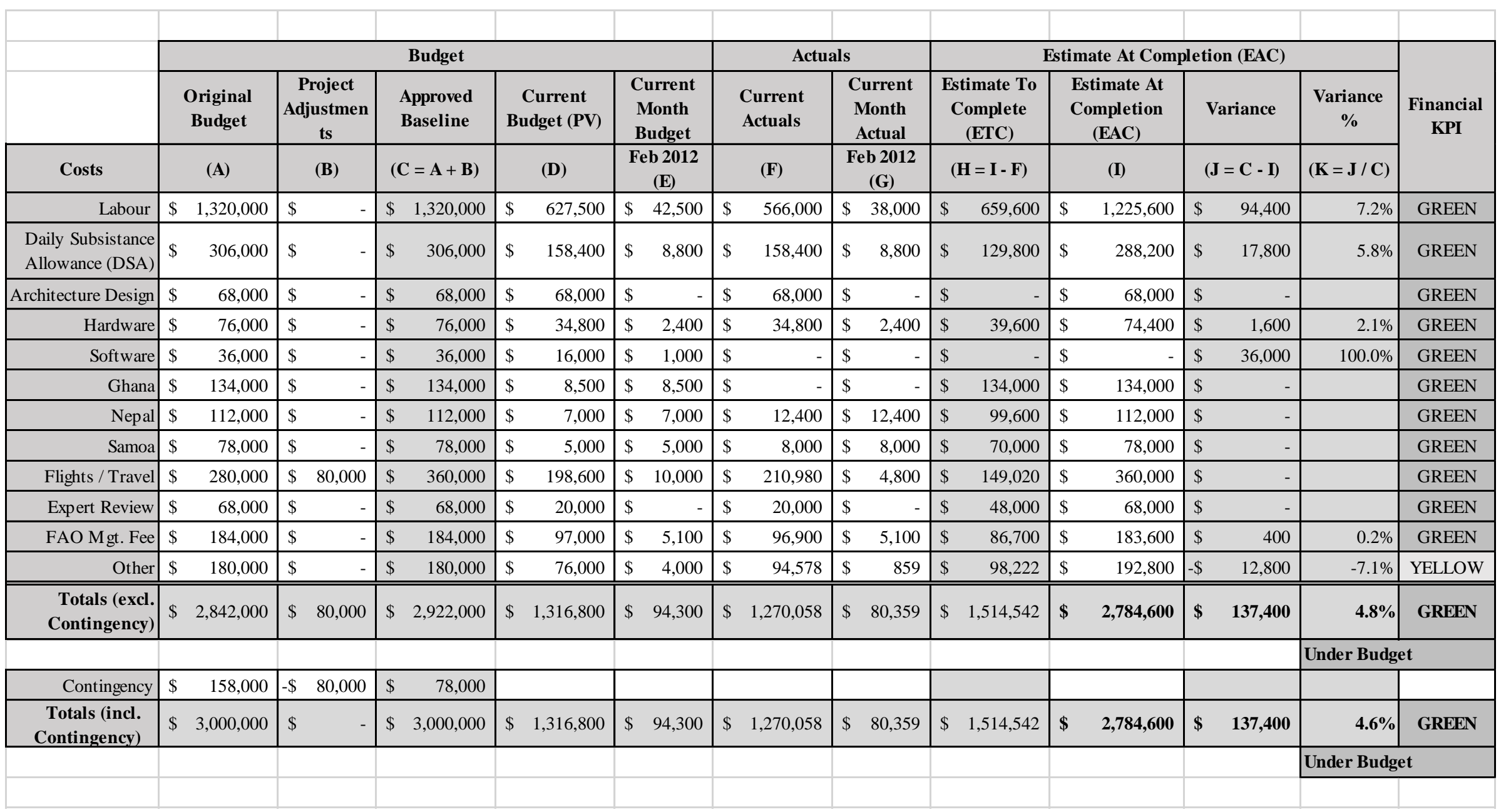

Figure 2: Libre LAS Project Financial Status: Feburary 2012 
Task:

Reporter:

Period Ending: 31 August 2012

\section{Progress Report}

\begin{tabular}{|c|c|c|}
\hline Status & : & \\
\hline Summary & $\begin{array}{l}\text { Lands Commission has finalised its business process re- } \\
\text { engineering exercise. The changes mean that Libre LAS Ghana } \\
\text { will not be ready for deployment until next year. }\end{array}$ & $\because$ \\
\hline Activities & $\begin{array}{l}\text { - Meetings and discussions on revised workflows } \\
\text { - } \quad \text { Meetings and discussions on Libre LAS architecture } \\
\text { - Investigating tools to support data transfer between Libre } \\
\text { LAS instances } \\
\text { - Developing migration scripts to transfer spatial data from } \\
\text { Land Commission GIS into Libre LAS }\end{array}$ & $\odot$ \\
\hline Plan & $\begin{array}{l}\text { - Progress against plan has been slow. } \\
\text { - Plan revised to reflect effort required to implement new } \\
\text { workflows. }\end{array}$ & $\because$ \\
\hline Budget & - Budget extended to include Rosa for 3 months. & $\odot$ \\
\hline Scope & $\begin{array}{l}\text { Lands Commission recently completed its workflow } \\
\text { process review. The revised workflows have been added to }\end{array}$ & 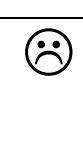 \\
\hline
\end{tabular}




\begin{tabular}{|c|c|c|c|c|c|}
\hline & \multicolumn{4}{|c|}{$\begin{array}{l}\text { the customisation scope. Expect it will require } 3 \text { to } 4 \\
\text { months development effort and testing }\end{array}$} & \\
\hline Resourcing & \multicolumn{4}{|c|}{$\begin{array}{l}\text { - Isaac has not completed any assigned development tasks } \\
\text { and Kwadwo has been extremely slow. } \\
\text { - } \quad \text { Rosa has joined team to speed up development. }\end{array}$} & $\ddot{\theta}$ \\
\hline \multirow[t]{7}{*}{$\begin{array}{l}\text { Timesheet } \\
\text { Summary }\end{array}$} & Name & Trips & $\begin{array}{c}\text { In Country } \\
\text { (Mths) }\end{array}$ & $\begin{array}{c}\text { Home Base } \\
\text { (Mths) }\end{array}$ & \multirow[t]{7}{*}{$\ominus$} \\
\hline & Pjeter & 3 & 1.5 & 5 & \\
\hline & Brett & 1 & 0.75 & 0.5 & \\
\hline & Rosa & 1 & 0.5 & 1.5 & \\
\hline & Kwadwo & & 5 & & \\
\hline & Isaac & & 5 & & \\
\hline & Totals & 5 & 11.75 & 7 & \\
\hline
\end{tabular}

\begin{tabular}{|l|l|c|}
\hline Risks & $\begin{array}{l}\text { Workflow processes are overly complex and restrictive. The } \\
\text { proposed process includes 11 steps and several checkpoints that } \\
\text { must be completed before an application can proceed. } \\
-\quad \text { Ensure Lands Commission staff have been fully briefed on } \\
\text { the new workflow steps. } \\
\quad \begin{array}{l}\text { Provide How To instructions that staff can reference when } \\
\text { completing steps }\end{array}\end{array}$ & $\ddots$ \\
\hline Issues & $\begin{array}{l}\text { Isaac has worked with Sabir on the business process re- } \\
\text { engineering but has not completed any of his assigned }\end{array}$ & \\
development tasks.
\end{tabular}




\begin{tabular}{|l|l|}
\hline \multirow{2}{*}{} & $\begin{array}{l}\text { Both Sabir and Isaac believe the Libre LAS architecture is overly } \\
\text { complicated and should be simplified. They are advocating for a } \\
\text { basic web solution rather than the multi-tier desktop solution. } \\
\text { Sabir has backing from the head of IT at the Lands Commission. }\end{array}$ \\
\cline { 1 - 2 } & $\begin{array}{l}\text { The Lands Commission has requested that Libre LAS is installed } \\
\text { in two regional offices that are not connected by any network. } \\
\text { manual data transfer process to synchronise data in each instance. }\end{array}$ \\
\cline { 1 - 2 } & $\begin{array}{l}\text { The Ghana pilot will not be ready for deployment before Feb next } \\
\text { year }\end{array}$ \\
\hline
\end{tabular}

Figure 3: Progress Report Ghana pilot 
Task: $\quad$ Libre LAS - Nepal Pilot

Reporter: Anatoly

Period Ending: 30 September 2012

\begin{tabular}{|c|c|c|c|c|c|}
\hline \multicolumn{6}{|c|}{ Progress Report } \\
\hline \multicolumn{3}{|l|}{ Status } & \multicolumn{2}{|l|}{ : } & \\
\hline Summary & \multicolumn{4}{|c|}{$\begin{array}{l}\text { Changes to GIS functions largely complete and only need testing. } \\
\text { Nepalese language has been added. Nepalese calendar in progress. } \\
\text { Ministry no longer supporting Libre LAS project. }\end{array}$} & 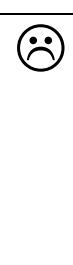 \\
\hline Activities & \multicolumn{4}{|c|}{$\begin{array}{l}\text { - Nepalese language added. } \\
\text { - } \quad \text { GIS changes completed. }\end{array}$} & $\odot$ \\
\hline Plan & \multicolumn{4}{|c|}{ - Slow progress due to frequent network and power failures. } & : \\
\hline Budget & \multicolumn{4}{|c|}{ - No changes. } & (:) \\
\hline Scope & \multicolumn{4}{|c|}{$\begin{array}{l}\text { Ministry never confirmed scope of title registration } \\
\text { functionality. Focus of development effort has been on } \\
\text { cadastral functions. }\end{array}$} & 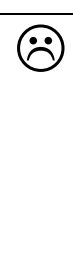 \\
\hline Resourcing & \multicolumn{4}{|c|}{$\begin{array}{l}\text { - Dipendra and Naresh have finished their contracts. } \\
\text { - } \quad \text { Production server has not been ordered as Ministry have } \\
\text { nowhere to install it. }\end{array}$} & $\odot$ \\
\hline \multirow[t]{3}{*}{$\begin{array}{l}\text { Timesheet } \\
\text { Summary }\end{array}$} & Name & Trips & $\begin{array}{c}\text { In Country } \\
\text { (Mths) }\end{array}$ & $\begin{array}{c}\text { Home Base } \\
\text { (Mths) }\end{array}$ & $(\dot{\theta}$ \\
\hline & Anatoly & 4 & 2 & 5 & \\
\hline & Brett & 1 & 0.25 & 0.5 & \\
\hline
\end{tabular}




\begin{tabular}{||l|l|l|c|c||}
\hline & Paras & & 6 & \\
\cline { 2 - 6 } & Dipendra & & 4.5 & \\
\cline { 2 - 6 } & Naresh & & 5 & \\
\cline { 2 - 6 } & Totals & 5 & 17.75 & 5.5 \\
\hline
\end{tabular}

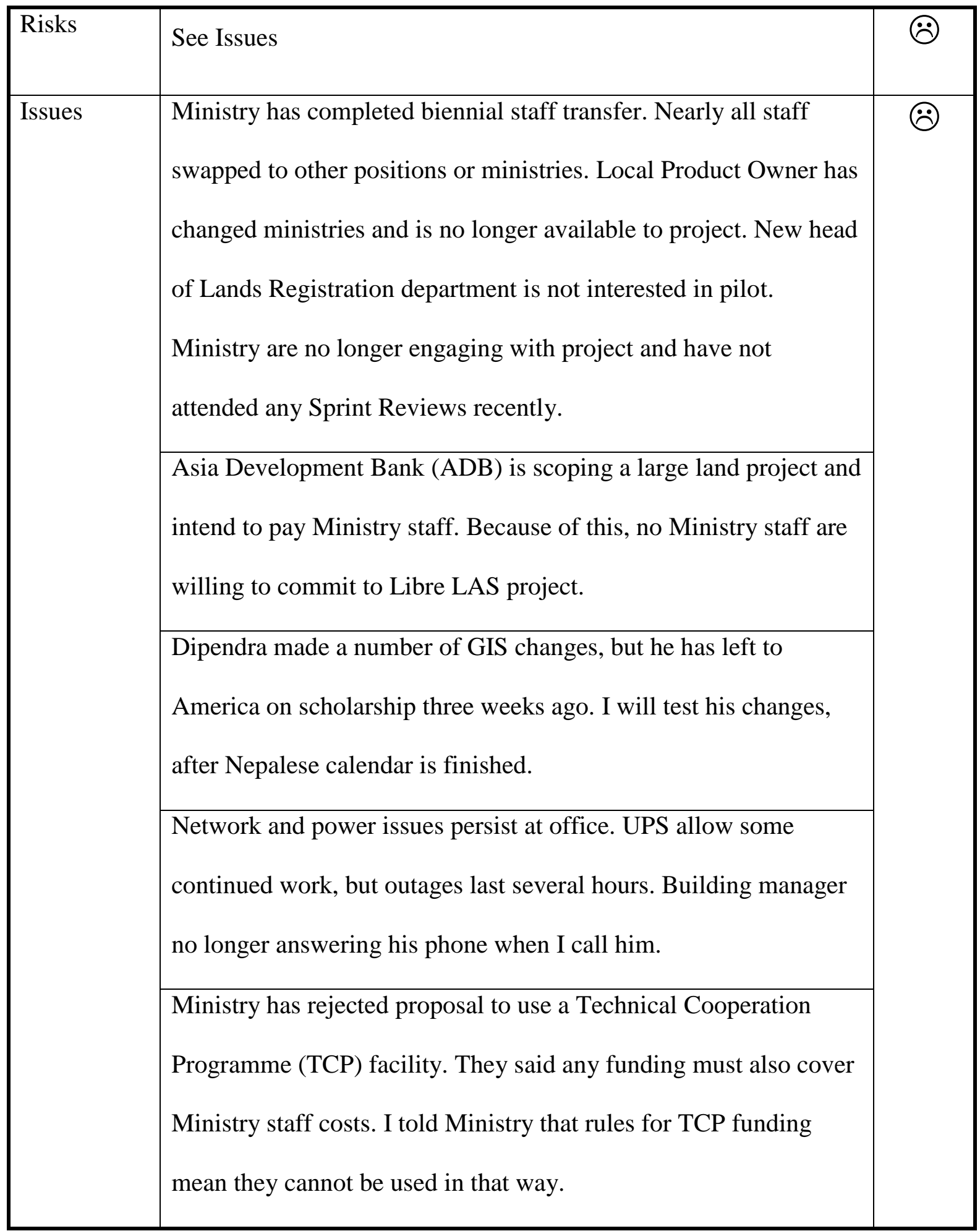


Figure 4: Progress Report Nepal pilot 
Task: $\quad$ Libre LAS - Samoa Pilot

Reporter: Nigel

Period Ending: 31 October 2012

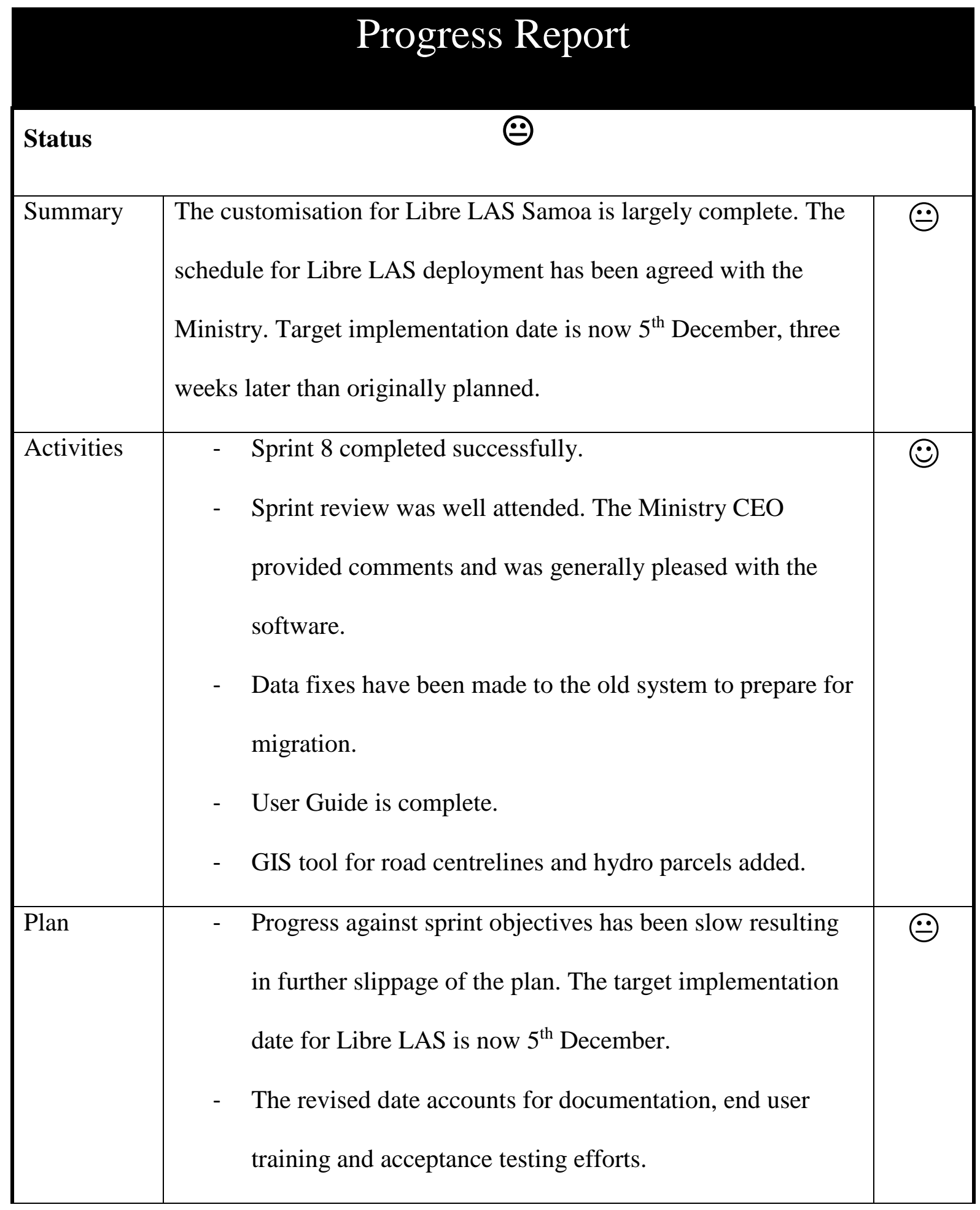




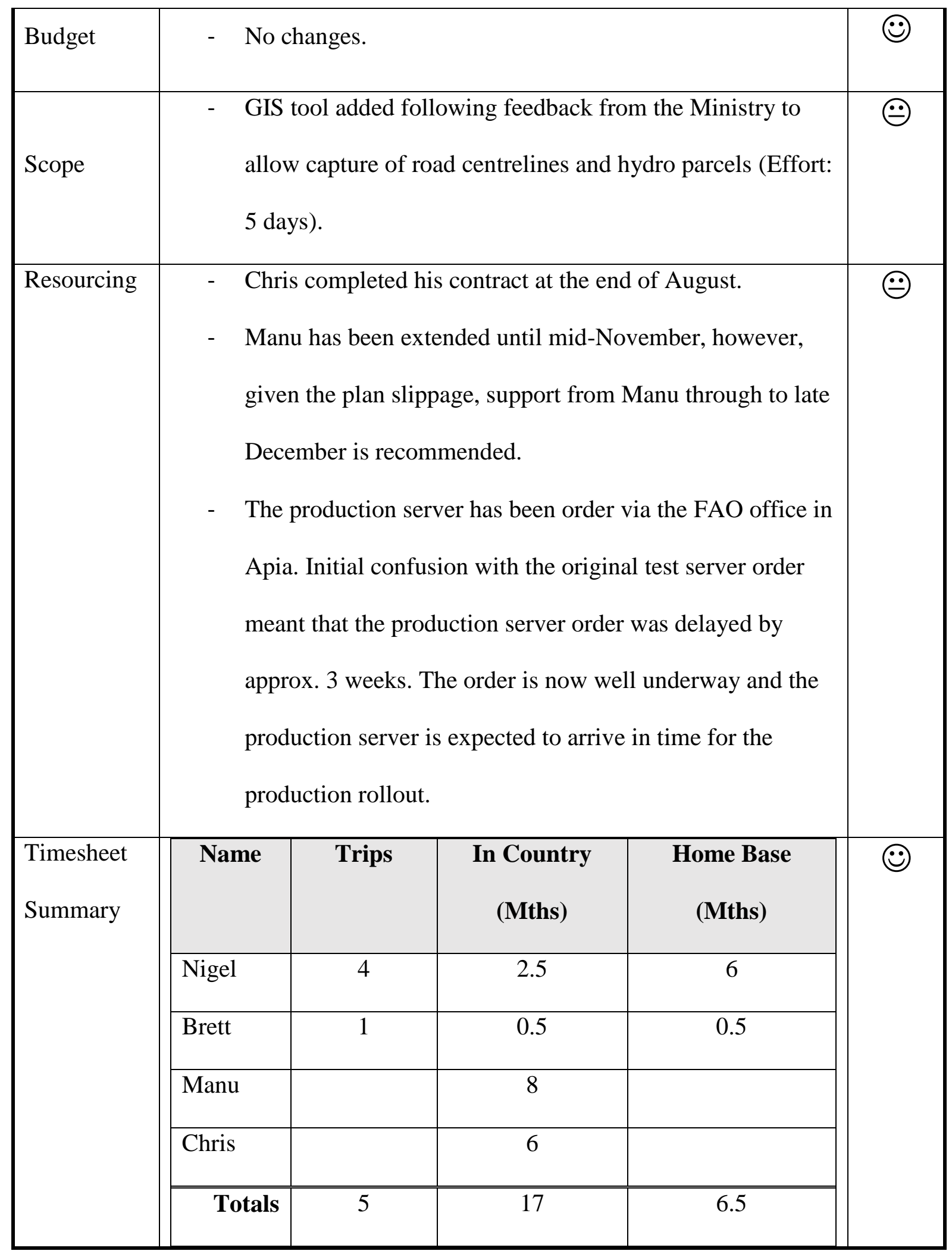

\begin{tabular}{|l|l|c|}
\hline Risks & $\begin{array}{l}\text { Pilot software not accepted by Ministry for production } \\
\text { deployment. }\end{array}$ & $\odot$ \\
\hline
\end{tabular}




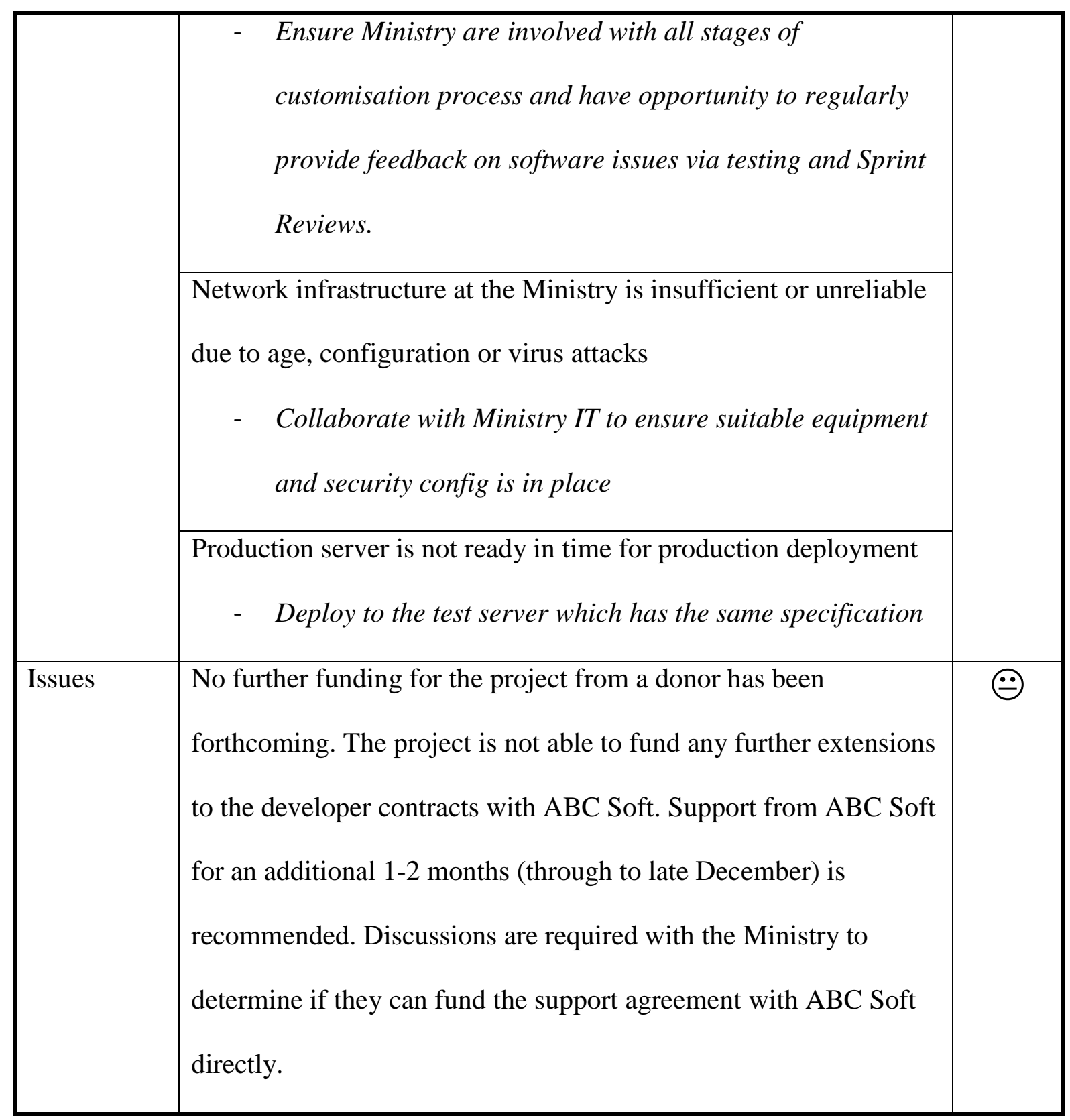

Figure 5: Progress Report Samoa pilot 